\title{
SPATIAL BEHAVIOUR OF TOURISTS IN BELGRADE
}

\author{
Aljoša Budović1*, Ivan Ratkaj* \\ * University of Belgrade - Faculty of Geography, Studentski trg 3/III, Belgrade
}

\begin{abstract}
For the purpose of destination planning, management and marketing it is imperative to understand the patterns of tourist spatial activities within cities; in the sense of delineating of tourist zones and major pathways, prognosis of the time spent at particular locations and realizing factors which shape the movement of tourists. The aim of this research is to outline the areas intensively used by tourists during their stay in Belgrade and to analyse the influence of various factors on their spatial behaviour. To collect relevant data, 325 foreign individual tourists were interviewed with the aim of collecting data regarding their spatial activities, visit specifics and socio-demographic characteristics. Independent t-test and oneway variance analysis (ANOVA) procedures were conducted in order to explore statistically significant differences in spatial behaviour of tourists based on their socio-demographic and visit characteristics. The study confirmed the importance of Belgrade's historical area for tourism and identified various factors regarding internal characteristics of their visit to the influences characterizing spatial behaviour of tourists in Belgrade. The results can be used to create long-term strategies that would promote a polycentric and balanced distribution of tourist activities across Belgrade and in turn prevent negative effects on the city life itself.
\end{abstract}

Key words: spatial behaviour, urban tourism, Belgrade

\section{Introduction}

Spatial behaviour of tourists refers to their spatio-temporal activities within a destination, usually defined by a sequence of movements and visited attractions (Xia, 2007). Understanding the patterns of tourist spatial activities in cities,

1 Corresponding author: A. Budović, University of Belgrade - Faculty of Geography, Studentski trg 3/III, Belgrade; e-mail: abudovic@gef.bg.ac.rs 
in sense of delineation of tourist zones and major pathways, prognosis of the time spent at particular locations, and revealing the factors that shape tourist movements, is of specific applicative importance for the processes of destination planning, management and marketing. The comprehensive knowledge about the ways in which tourists consume city space should facilitate sustainable development of urban tourism based on measures that promote more uniform distribution of tourist activities, improve both tourist suprastructure and infrastructure, and balance the needs of tourists and local community (Edwards \& Griffin, 2013; Kadar \& Gede, 2013). Accurate information on patterns of tourist spatial behaviour might alleviate or prevent negative effects which often follow development of mass urban tourism and affect all city dwellers. Increased spatial concentration of tourists in the city is the predominant cause of negative effects, such as traffic jams, overcrowded pedestrian areas, cultural and historical heritage sights becoming endangered, displacement of city functions in compatible with tourist needs, increased prices, rise of crime and deviant activities, etc. (Edwards et al., 2010; Kadar, 2014). Uneven spatial and temporal distribution of tourists disrupts the carrying capacity (ecological, psychological and socio-cultural) of urban tourist destinations causing decreased quality of the tourist experience, on one side, and dissatisfaction or even the eviction of local population from areas that tourists intensively use, on the other (Jovičić, 2008). Dispersion of tourist activities in a spatial sense can be achieved by establishing new tourist attractions and better promotion of existing ones; revitalization of old neglected quarters; decentralization of tourist services; placing suitable signalization which promotes alternative travel routes; expansion of pedestrian zones; organization of various visitation intervals, etc. (Vu et al., 2015).

Cities are complex, multidimensional and multifunctional tourist destinations with multipurpose visits ${ }^{2}$ (Ashworth \& Page, 2011; Ratkaj, 2012), which produce specific spatial patterns of tourist activities. Visitors are drawn to cities by a variety of functions, facilities, built forms, cultures or peoples, rather than by a single urban feature, causing spatial activities of variously motivated tourists to blend (Ashworth \& Page, 2011). For example, business-centric or VFR (visiting friends and relatives) tourists spend some time visiting urban cultural attractions, while cultural tourists also visit shopping or recreational zones. In addition, various amenities and areas that are attractive to tourists are primarily also intended to be used by the local population of cities (Shoval et al., 2011; Kadar, 2014), which creates methodological difficulties in differentiating tourists from the local population and blends the impact of tourism in the city.

Spatial selectivity is the central attribute of tourist behaviour in cities. Tourists, as well as city residents, use only a limited part of the city space and

2 Many of which are not primarily motivated by holidaymaking. 
services for their needs (Ashworth \& Page, 2011). Tourist activities are concentrated in relatively small areas, determined by the distribution of primary and secondary elements of the city's tourism product, producing unique micro geographies (Pearce, 2001; Maitland \& Newman, 2004, Ashworth \& Page, 2011). Spatial selectivity is not inherent only to urban, but also to other types of tourist destinations. Yet, this is particularly amplified in cities due to their size and morphology (Shoval et al., 2011), as well as relatively shorter tourist visits (Ashworth \& Page, 2011).

Studying the spatial behaviour of tourists is essential both for popular cities, facing various negative effects of mass tourism, and particularly for emerging destinations. Over the last five years, the number of tourist arrivals in Belgrade has grown from 620.000 to 915.000 (Secretariat for Administration - Sector for statistics, 2016). Although negative consequences of tourism development are not recorded in existing literature when touching upon Belgrade, uncontrolled continuation of this trend could cause developing systemic issues in the near future. Several recent studies emphasized the process of increased concentration of tourist activities in within Belgrade's historic area (Budović et al., 2015; Todorović \& Deđanski, 2016), however without the analysis of underlying factors needed for a deeper understanding of tourist spatial behaviour.

The aim of this research is to outline the areas intensively used by tourists during their stay in Belgrade and to analyse the influence that various factors have on their spatial behaviour. For this purpose, data on spatial activities of tourists, their socio-demographic characteristics, and character while visiting were used. The results of this study can be used in the process of strategic planning, management and marketing of tourism in Belgrade in order to prevent possible negative effects and to provide basis for more sustainable development.

\section{Spatial behaviour of tourists}

Studies of human spatial behaviour were revolutionized by the emergence of a behavioural approach in human geography during the late 1950s and early 1960s, as a critique of simplistic and deterministic models based on the spatially and economically perfect rational behaviour of a man who possesses all the relevant information (Grčić, 1994; Golledge, 2008). The concept of perfectly rational human behaviour was replaced by "the concept of imperfectly rational man with different abilities and most often incomplete or deformed information" (Grčić, 1994, pp. 67-68), whose "spatial behaviour does not depend only on the external physical and social factors, but also on the subjective motives and decisions" (Grčić, 2012, pp. 11). Behaviouralism in geography transformed research on the interaction between man and his environment by using disaggregated behaviour data and new analytical and data collection methods (Golledge, 2008). 
Despite the evident need for empirical (and theoretical) research, a thorough analysis of tourist spatial behaviour in cities have not been conducted until the last decade of the 20th century (Murphy, 1992; Keul \& Kühberger, 1997). This can be partially explained by methodological difficulties such as locating tourists within the city space, locating places where they enter or leave the city, and differentiating tourists from the local population, among other factors. Moreover, collecting data on tourist movements is time consuming and financially demanding process (Shoval, 2012), which can be significantly aided by utilization of modern information and communication technologies (Shoval et al, 2011; Freytag, 2010).

Spatiotemporal activities of tourists in cities are not random, rather are defined by external and internal factors as well as by the character of their trip (Zillinger, 2007; Shoval \& Isaacson, 2010). External factors refer to the distribution of primary and secondary elements of urban tourist product, but also to urban morphology, transport system, crowding etc. Although visitors are likely to be attracted by any or all of the primary elements or urban tourist product (Ashworth \& Page, 2011), urban cultural heritage often emerges as the key force that shapes patterns of tourists' spatial behaviour (Urry, 1990; Ashworth \& Tunbridge, 2000; Williams 2009). Urban morphology defines main routes which tourists rarely leave in order to explore additional Streets away from urban attractions (Kadar, 2014). Locations of accommodation (Shoval et al., 2011), familiarity with public transport system (Edwards and Griffin, 2013) and crowding (Neuts \& Nijkamp, 2012) are also relevant to the movements of tourists.

Internal factors relate to psychological, social and demographic characteristics of tourists. A number of studies on tourist behaviour revealed its dependence on variables such as country of origin (Yan, 2003), age (Fleischer \& Pizam, 2002; Chan et al, 2013), education, income (Mok \& Iverson, 2000), religious affiliation (Shachar \& Shoval, 1999), gender (Chan et al, 2009; Chan et al, 2013), and personality type (McKercher \& Lau, 2008). However, authors exist that are prone to deny the influence of internal factors on tourist spatial activity (Debbage, 1991; Gali-Espelt \& Donaire Benito, 2006; etc.).

The character of their trip includes purpose of visit, length of stay, repetition of visit, organizational structure of the trip and other attributes, which can all modify tourist activities. Behaviour of tourists with specific interests is more spatially constrained than of the tourists with general interests (Fennell, 1996). The duration of their visit is an important factor that limits which limits the amount of locations they can visit within an allocated time. Therefore, the spatial behaviour of tourists staying for a certain length at the destination is considerably different than that of day visitors (McKercher, 2001; McKercher, et al., 2006; Gali-Espelt \& Donaire Benito, 2006; Shoval, 2012). The temporal-spatial activities of tourists with repeated visits are more selective. They use return vis- 
its to see additional tourist attractions or to spend more time in preferable places (Kempermann et al., 2004; Gali-Espelt \& Donaire Benito, 2006; McKercher et al., 2012). The tourists can be divided into two broad categories based on the organizational structure of a trup: "individual tourists" and "tourists travelling in organized groups". The main difference is that the itinerary of organized groups is prepared and known in advance, while individual tourists have freedom to choose sites they prefer to visit (McKercher, et al, 2006; Shoval \& Isaacson, 2010).

\section{Research methodology}

According to the criteria of researcher participation, there are two basic groups of methods of collecting spatial and temporal data on tourist behaviour: direct observation techniques and non-observational techniques (Shoval \& Isaacson, 2010).

Direct observation techniques obligate the researcher to monitor and record the movements of visitors from appropriate distance. These techniques provide information on tourist behaviour in space only, leaving tourist profile and motivation unknown. Because of this limitation, direct observation techniques are rarely used in practice (Keul \&Kühberger, 1997; Shoval \& Isaacson, 2010).

Non-observational techniques allow researcher to monitor the behaviour of tourists for a limited amount of time, usually from one to seven days. They include keeping a travel diary or, more often, interviewing or surveying at the end of a trip (Debbage, 1991; Shoval \& Isaacson, 2010). With these techniques, information about the visited sites, duration and sequences of the visits, and movement paths can be collected in a short period of time. Dependence on the ability and willingness of the participant to memorize and reproduce the sites they visited and the activities they undertook is the main drawback of these techniques and it can significantly affect the quality of the gathered data. During the last decades, non-observational techniques in social sciences have been gradually combined with the use of modern technologies such as the global positioning system (GPS), land-based tracking systems, smart mobile phones, bluetooth, and visual and the analytical potential of GIS (Shoval \& Isaacson, 2007; Edwards et al., 2010; Versichele et al., 2012; Balint, 2014, Zoltan \& McKercher, 2015).

Interviews and questionnaires were the non-observational techniques used in this study. Individual foreign tourists were met at the end of their visit to Belgrade, at the main railway and bus station. Data was collected by students from the Faculty of Geography in Belgrade during the summer of 2013, as part of broader research on tourism demand in Belgrade (Todorović et al., 2015; Todorović et al., 2017). Individual foreign tourists and their spatial behaviour was chosen as the focus due to two main reasons: first, their share in the 
total number of tourist arrivals and overnight stays in Belgrade has been rapidly increasing, and second, they personally select the tourist sites they choose to visit (McKercher \& Lau, 2008). The questionnaire used in this survey was a partially modified standardized questionnaire of the Association for Education on Tourism and Leisure (ATLAS, 2013). The aim was to gather the socio-demographic information about tourists, the nature of their trips, as well as the data about their spatial activities, which deemed one open-ended question to be added as part of the typical survey. Tourists were asked to answer this question in regards to the sites which they visited, solely based on memory.

Out of the 328 collected questionnaires, 325 were taken into account and analyzed in this study. Responses with spatially undefined locations, activities or wider urban areas were considered in the analysis of the factors influencing tourist spatial behaviour. Participants named 49 different sites in Belgrade, with a total number of 1,455 recorded visits, or 4.48 visits on average. A relatively smaller average number of visited sites does not imply that tourists did not visit other sites in the city, but rather confirms the hypothesis about the limited ability of tourists to recall all the sites they visited. The varying number of visits by tourists to sites in Belgrade is shown in maps (figure 1 and figure 2). Maps also indicate an area known as the historic centre (Old Belgrade), which is currently under a process of protection as a Belgrade cultural heritage area (Belgrade City Institute for the Protection of Cultural Monuments, 2015).

Table 1. Socio-demographic and trip characteristics of the participants

\begin{tabular}{|c|c|c|c|}
\hline Characteristics & Categories & Results in \% & Sample \\
\hline \multirow{2}{*}{ Age } & $18-25$ & 84.28 & \multirow{2}{*}{318} \\
\hline & $26+$ & 15.72 & \\
\hline \multirow{2}{*}{ Gender } & Male & 55.69 & \multirow{2}{*}{325} \\
\hline & Female & 44.31 & \\
\hline \multirow{3}{*}{ Education } & Secondary or less & 50.33 & \multirow{3}{*}{304} \\
\hline & Bachelor degree & 36.18 & \\
\hline & Master degree and PhD & 13.49 & \\
\hline \multirow{2}{*}{ Origin } & European & 90.15 & \multirow{2}{*}{325} \\
\hline & Non-European & 9.85 & \\
\hline \multirow{4}{*}{$\begin{array}{l}\text { Household annual } \\
\text { income in Euros }\end{array}$} & $<5,000$ & 19 & \multirow{4}{*}{279} \\
\hline & $5,001-30,000$ & 44.09 & \\
\hline & $30,001-60,000$ & 22.58 & \\
\hline & $>60,001$ & 14.34 & \\
\hline \multirow{2}{*}{ Repetition } & First visit & 86.77 & \multirow{2}{*}{325} \\
\hline & Previous visits & 13.23 & \\
\hline \multirow{3}{*}{ Length of stay } & Daily visitors & 20.62 & \multirow{3}{*}{325} \\
\hline & One or two nights & 51.08 & \\
\hline & Three or more nights & 28.31 & \\
\hline
\end{tabular}


Independent t-test and one-way variance analysis (ANOVA) procedures were conducted in order to explore statistically significant differences in tourists' spatial behaviour based on their socio-demographic (origin, age, gender, education and household annual income) and trip characteristics (repetition and length of stay). These dependant variables were not tested for all of the listed sites, but only for those visited by more than $20 \%$ of total participants. Education, household annual income and length of stay, as dependant variables, were posthoc analyzed by the Bonferroni test for the sites where statistically significant differences were observed.

\section{Results and discussion}

Socio-demographic and data based on trip characteristics are provided in table 1 . Out of 325 participants, $55.7 \%$ are males. The average age of the participants is 22.9 years and $90.1 \%$ of them originate from Europe. The majority are students $(73 \%)$ with finished high school (38.6\%) and/or with bachelor degrees $(36.2 \%)$. More than a two-thirds $(75.4 \%)$ of participants stayed in hostels, while only $10.6 \%$ in hotels. On average, they spent 19 days on holiday, whereby Belgrade was not the primary destination for $85.9 \%$ participants. Most of the participants $(86.3 \%)$ visited Belgrade for the first time and stayed there for approximately two to three days. One-fifth of participants were designated as tourists in transit. Participants on average spent 91.6 euros per day during their stay. They were generally satisfied with their stay in Belgrade $(90.5 \%)$ and would recommend others to visit Belgrade (88.3\%).

Based on the collected data about the sites visits in Belgrade, this study confirmed spatially uneven distribution of tourist activity. Number of visited sites and their importance decreased once the data moved away from the centre of Old Belgrade, with a few exceptions. This proves that the tourist movements in Belgrade are dependent on the spatial distribution of primary and secondary elements of tourist product, which are concentrated in the historic centre.

Results of the study confirm that Old Belgrade is the most visited tourist area in Belgrade, whereby $95 \%$ of all participants visited at least one of the 34 sites belonging to that area. Sites that tourists visited within the territory of Old Belgrade are grouped in the zone around its central axis, which extends from the Belgrade Fortress to the Church of St. Mark. In this zone, which in turn includes 27 different locations, $81.5 \%$ of the participants visited the Belgrade Fortress which is followed by Knez Mihailova Street with $61.2 \%$ (the main pedestrian area), the Republic Square with 35.1\% (the main public square), Skadarska Street with 26.5\% (Bohemian quarter), the National Assembly of the Republic of Serbia with $22.1 \%$, the Church of St. Mark with $17.53 \%$, etc. Outside this zone, but still 
in Old Belgrade, sites that emerged as relevant attractions were: the Temple of Saint Sava, visited by $43.69 \%$ of surveyed tourists, the Museum of Nikola Tesla with $11.08 \%$, and the Army Headquarters Building damaged in NATO bombing with $10.15 \%$.

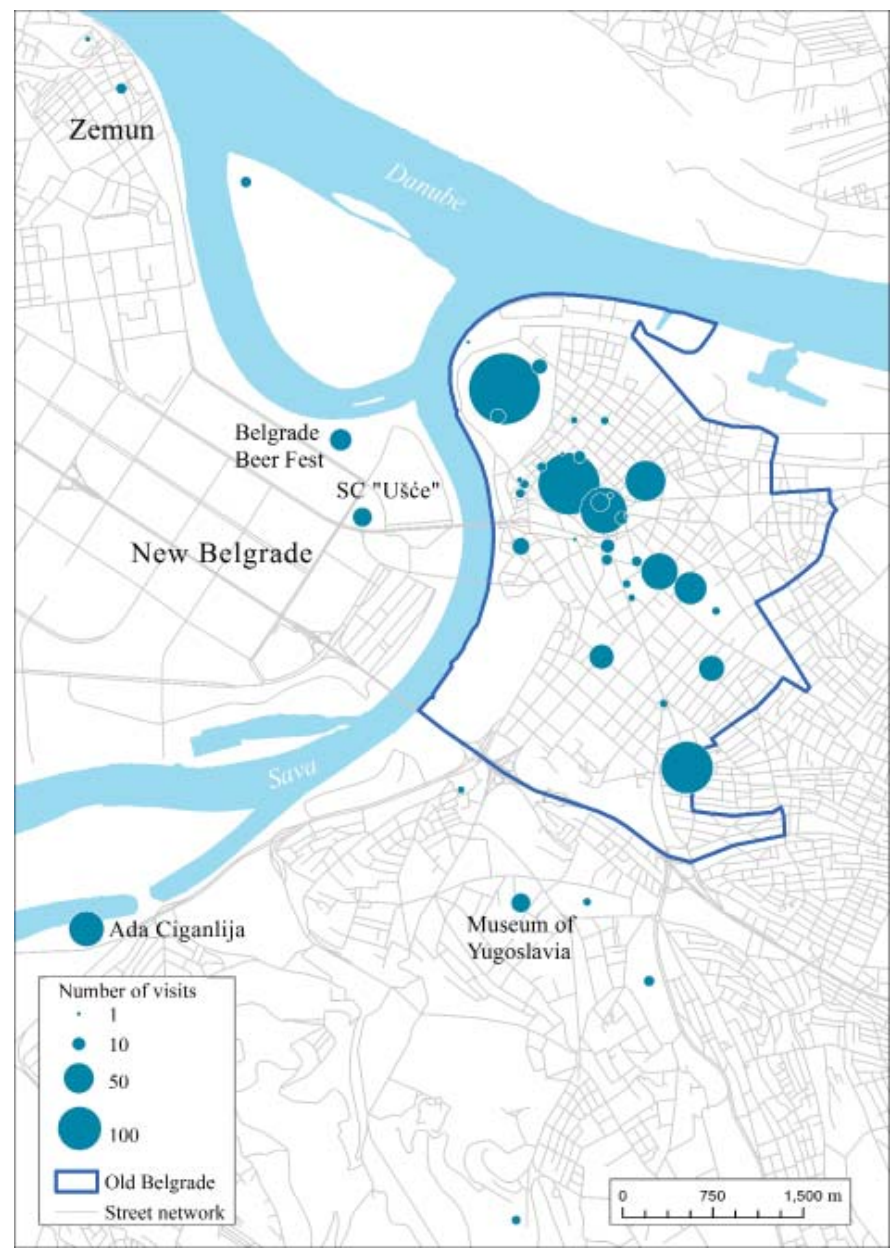

Figure 1. Sites visited by tourists in Belgrade

Spatial distribution determined that tourists used the Belgrade Fortress and Temple of St. Sava as endpoints within the zone of Old Belgrade as main sites of interest. This meant that the streets of Knez Mihailova, Kralja Milana and Terazije Square endured intensive pressure from tourist activities. In conclusion, future action on redistribution of tourist activities and pathways within Belgrade's historic centre should be prioritized to these core streets and sites. 


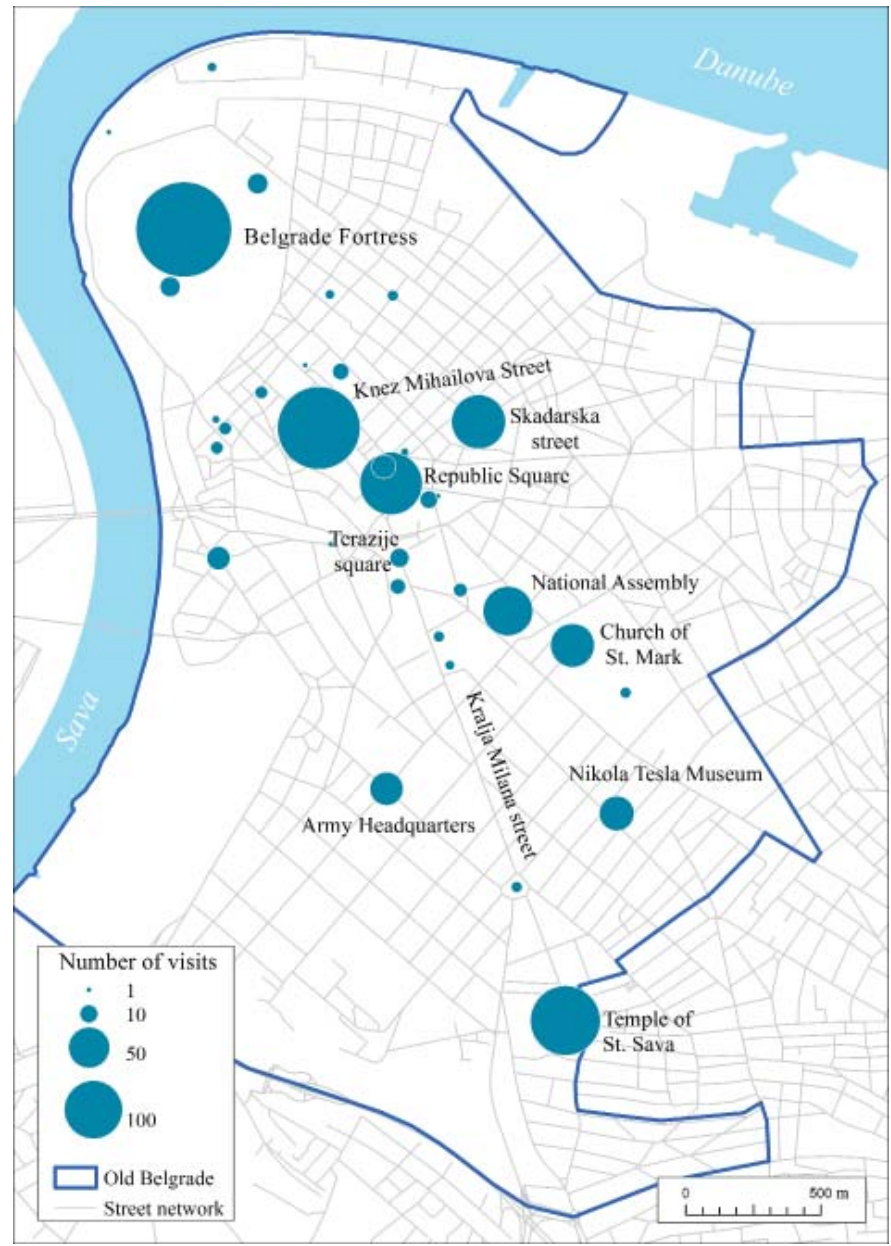

Figure 2. Sites visited by tourists in area of Old Belgrade

The city riverfront area, with recreation and entertaining amenities, emerged as the second most popular tourist zone in Belgrade. In this zone, the restaurants and floating river clubs ("splavovi") ${ }^{3}$ stood out as the most important with $21.85 \%$ of participants, and are followed by artificial Lake Ada Ciganlija with $20.62 \%$ of participants, and the banks of the Danube and Sava rivers with $16.31 \%$ and $2.46 \%$, respectively. Visits to the Belgrade riverfront reflect the capacity of its recreation and the value within its entertainment functionality for foreign visitors. This area is important for diversification and decentralization of the

3 Restaurants and floating river clubs are scattered along Sava riverbanks and right Danube riverbank. 
city's tourist product. Its popularity among visitors can be explained by the age structure of the participants, but is also the result of a marketing campaign performed by the Tourist Organization of Belgrade, and of numerous foreign news articles describing the lucrative entertainment and night life in the Serbian capital (Sherwood, 2005; Cartwright, 2009; Cohen et al., 2013).

New Belgrade and Zemun, with exception of the riverfront area, have a share of only $20 \%$ of visits. This includes the Belgrade Beer Festival, visited by $8 \%$ of tourists, and shopping centre "Ušće" with $6.46 \%$ of visits. Outside of these areas, only the Museum of Yugoslavia stands out, visited by $6.46 \%$ of all participants.

Analysis of socio-demographic factors showed that they have no major influence on patterns of spatial behaviour of tourists, with exception of household annual income (Table 2). The analysis of age differences showed that younger tourists had visited the Republic Square $(\mathrm{F}=45.88, \mathrm{p}<.05)$ and the Ada Ciganlija $(\mathrm{F}=4, \mathrm{p}<.05)$ more often than the older ones. Men were more interested in visiting the Republic Square $(\mathrm{F}=22.46, \mathrm{p}<.05)$ and especially floating river clubs $(\mathrm{F}=29.03, \mathrm{p}<.01)$, than women were. Participants who completed elementary or high school were more attracted by Knez Mihailova Street $(F=3.99, p<.05)$ compared to those with a bachelor degree, while the opposite was true for Ada Ciganlija $(\mathrm{F}=3.87, \mathrm{p}<.05)$. The results of the survey indicate that tourists from non-European countries visited fewer locations in comparison to Europeans, which is particularly pronounced for the locations that are further away from the core of Old Belgrade. However, statistically significant variations were recorded for the purpose of Temple of St. Sava $(F=222.2, p<.01)$. This can be explained by the fact that tourists from culturally proximate markets (Europe) have more knowledge about the city which resulted in wider scope of movements within it (McKercher et al, 2006). ANOVA's analysis of the influence of household annual income on the patterns of spatial behaviour showed a number of statistically significant variations. It is particularly interesting to point out that the most affluent group visited the pedestrian area of Knez Mihailova Street $(\mathrm{F}=$ $6.42, \mathrm{p}<.01)$, the Republic Square $(\mathrm{F}=5.62, \mathrm{p}<.01)$ and the Skadarska Street $(\mathrm{F}$ $=2.62, \mathrm{p}<.05)$ more often, which can be explained by the presence of exclusive restaurants and high-end shops in the area. Also, this group of participants was more interested in nightlife of floating river clubs $(F=4.60, p<.01)$. One of the reasons for these results could be the sample size of certain respondent categories (older tourists, tourist from non-European countries, etc.). Explanation of some statistically significant variations, like ones found for the Republic Square (dominantly visited by younger males and visitors with completed primary or secondary school), requires additional research and more information. 
Table 2. ANOVA and t-test results for socio-demographic characteristics and visited sites in Belgrade

\begin{tabular}{|c|c|c|c|c|c|c|c|c|c|}
\hline $\begin{array}{l}\text { Socio-demog. } \\
\text { Variable }\end{array}$ & Category & $\begin{array}{c}\text { Belg. } \\
\text { Fortress }\end{array}$ & $\begin{array}{l}\text { Knez- } \\
\text { Mih. } \\
\text { Street }\end{array}$ & $\begin{array}{c}\text { Rep. } \\
\text { Square }\end{array}$ & $\begin{array}{l}\text { Skad. } \\
\text { Street }\end{array}$ & $\begin{array}{c}\text { National } \\
\text { Assem. }\end{array}$ & $\begin{array}{c}\text { Saint } \\
\text { Sava } \\
\text { temp. }\end{array}$ & $\begin{array}{l}\text { Ada } \\
\text { Cigan. }\end{array}$ & $\begin{array}{c}\text { Float. } \\
\text { river } \\
\text { clubs }\end{array}$ \\
\hline \multirow{4}{*}{ Age } & $18-25$ & 0.82 & 0.60 & 0.42 & 0.27 & 0.25 & 0.43 & 0.22 & 0.22 \\
\hline & $26+$ & 0.82 & 0.66 & 0.26 & 0.26 & 0.12 & 0.52 & 0.10 & 0.18 \\
\hline & $F$ & 0.01 & 0.55 & 4.44 & 0.02 & 3.86 & 1.41 & 4.00 & 2.12 \\
\hline & Sig & 0.94 & 0.46 & $0.04^{*}$ & 0.90 & 0.05 & 0.24 & $0.05^{*}$ & 0.49 \\
\hline \multirow{4}{*}{ Gender } & Male & 0.84 & 0.64 & 0.45 & 0.25 & 0.22 & 0.46 & 0.22 & 0.27 \\
\hline & Female & 0.79 & 0.58 & 0.31 & 0.28 & 0.22 & 0.40 & 0.19 & 0.15 \\
\hline & $\mathrm{F}$ & 4.95 & 4.93 & 22.46 & 2.10 & 0.00 & 4.48 & 2.23 & 29.03 \\
\hline & Sig & 0.27 & 0.24 & $0.01^{*}$ & 0.47 & 0.98 & 0.27 & 0.46 & $.01^{* *}$ \\
\hline \multirow{4}{*}{ Origin } & European & 0.81 & 0.62 & 0.40 & 0.26 & 0.24 & 0.47 & 0.22 & 0.22 \\
\hline & $\begin{array}{c}\text { Non- } \\
\text { European }\end{array}$ & 0.91 & 0.50 & 0.31 & 0.34 & 0.09 & 0.16 & 0.13 & 0.19 \\
\hline & F & 9.47 & 2.10 & 5.51 & 3.29 & 20.35 & 222.20 & 7.29 & 0.87 \\
\hline & Sig & 0.18 & 0.17 & 0.36 & 0.29 & 0.07 & $0.00^{* *}$ & 0.23 & 0.66 \\
\hline \multirow{5}{*}{$\begin{array}{l}\text { Educa- } \\
\text { Tion }\end{array}$} & $\begin{array}{c}\text { Secondary } \\
\text { or less }\end{array}$ & 0.79 & 0.66 & 0.46 & 0.24 & 0.25 & 0.42 & 0.15 & 0.20 \\
\hline & Bachelor & 0.85 & 0.52 & $0.30 \mathrm{a}$ & 0.31 & 0.18 & 0.45 & $0.29 a$ & 0.28 \\
\hline & $\begin{array}{c}\text { Master or } \\
\text { PhD }\end{array}$ & 0.86 & 0.63 & 0.31 & 0.27 & 0.24 & 0.51 & 0.22 & 0.18 \\
\hline & $\mathrm{F}$ & 1.20 & 2.78 & 3.99 & 0.89 & 0.99 & 0.56 & 3.87 & 1.74 \\
\hline & Sig & 0.30 & 0.06 & $0.02^{*}$ & 0.41 & 0.37 & 0.57 & $0.02^{*}$ & 0.18 \\
\hline \multirow{6}{*}{$\begin{array}{l}\text { House. } \\
\text { annual } \\
\text { income in } \\
\text { Euros }\end{array}$} & $<5,000$ & $0.92 d$ & $0.45 f$ & 0.42 & $0.19 \mathrm{f}$ & 0.26 & $0.47 \mathrm{e}$ & 0.19 & $0.13 f$ \\
\hline & $5,001-30,000$ & $0.74 c, f$ & $0.57 \mathrm{f}$ & $0.28 \mathrm{f}$ & 0.28 & 0.21 & $0.43 \mathrm{e}$ & 0.27 & $0.22 \mathrm{f}$ \\
\hline & $\begin{array}{c}30,001- \\
60,000\end{array}$ & 0.83 & 0.63 & 0.38 & 0.30 & 0.21 & $0.25 \mathrm{c}, \mathrm{d}, \mathrm{f}$ & 0.25 & 0.24 \\
\hline & $>60,001$ & $0.93 d$ & $0.88 \mathrm{c}, \mathrm{d}$ & $0.63 d$ & $0.45 c$ & 0.25 & $0.48 \mathrm{e}$ & 0.13 & $0.45 c, d$ \\
\hline & $\mathrm{F}$ & 4.24 & 6.42 & 5.62 & 2.62 & 0.28 & 2.74 & 1.41 & 4.60 \\
\hline & Sig & $0.01^{* *}$ & $0.00^{* *}$ & $0.01^{* *}$ & $0.05^{*}$ & 0.84 & $0.04^{*}$ & 0.24 & $0.00^{* *}$ \\
\hline
\end{tabular}

* Significant at 0.05 level.

** Significant at 0.01 level.

Note: Table shows mean scores for all categories.

Note: a, b signify primary and secondary school, bachelor degree, respectively, and indicate particular destination mean score(s) differences detected by post hoc Bonferroni test.

Note: c, d, e and f signify Household annual income groups: less than 5,000, from 5,001 to 30,000, from 30,001 to 60,000 and more than 60,001 euro's, respectively, and indicate particular destination mean score(s) differences detected by post hoc Bonferroni test. 
Table 3. ANOVA and t-test results for trip characteristics and visited sites in Belgrade

\begin{tabular}{|c|c|c|c|c|c|c|c|c|c|}
\hline $\begin{array}{c}\text { Trip } \\
\text { charact. }\end{array}$ & Category & $\begin{array}{l}\text { Belg. } \\
\text { Fortress }\end{array}$ & $\begin{array}{l}\text { Knez } \\
\text { Mih. } \\
\text { Street }\end{array}$ & $\begin{array}{l}\text { Rep. } \\
\text { square }\end{array}$ & $\begin{array}{l}\text { Skad. } \\
\text { Street }\end{array}$ & $\begin{array}{c}\text { National } \\
\text { Assem. }\end{array}$ & $\begin{array}{c}\text { St. } \\
\text { Sava } \\
\text { temp. }\end{array}$ & $\begin{array}{l}\text { Ada } \\
\text { Cigan. }\end{array}$ & $\begin{array}{l}\text { Float. } \\
\text { river } \\
\text { clubs }\end{array}$ \\
\hline \multirow{4}{*}{ Repetition } & First visit & 0.84 & 0.62 & 0.40 & 0.28 & 0.24 & 0.44 & 0.21 & 0.23 \\
\hline & Prev. visit & 0.67 & 0.56 & 0.33 & 0.19 & 0.09 & 0.40 & 0.19 & 0.12 \\
\hline & $\mathrm{F}$ & 18.85 & 1.50 & 4.74 & 8.25 & 28.88 & 2.14 & 0.52 & 16.69 \\
\hline & Sig & $0.01^{* *}$ & 0.44 & 0.37 & 0.21 & $0.03^{*}$ & 0.56 & 0.73 & $0.04^{*}$ \\
\hline \multirow{5}{*}{$\begin{array}{l}\text { Length of } \\
\text { stay } \\
\text { (nights) }\end{array}$} & 0 & 0.76 & 0.69 & 0.37 & $0.12 b, c$ & 0.30 & 0.34 & $0.04 c$ & $0.06 c$ \\
\hline & $1-2$ & 0.86 & 0.58 & $0.46 c$ & $0.29 a$ & 0.23 & 0.46 & $0.14 \mathrm{c}$ & $0.18 \mathrm{c}$ \\
\hline & $3+$ & 0.79 & 0.61 & $0.26 b$ & $0.33 a$ & 0.15 & 0.47 & $0.43 a, b$ & $0.40 \mathrm{a}, \mathrm{b}$ \\
\hline & $\mathrm{F}$ & 1.70 & 1.05 & 5.30 & 4.88 & 2.48 & 1.52 & 25.14 & 16.05 \\
\hline & Sig & 0.18 & 0.35 & $0.01^{* *}$ & $0.01^{* *}$ & 0.09 & 0.22 & $0.00^{* *}$ & $0.00^{* *}$ \\
\hline
\end{tabular}

* Significant at 0.05 level.

** Significant at 0.01 level.

Note: Table shows mean scores for all categories.

Note: $a, b$ and c signify no overnights, one or two nights and three or more nights, respectively, and indicate particular destination mean score(s) differences detected by post hoc Bonferroni test.

The study results revealed that factors related to trip characteristics had considerable influence on tourist spatial behaviour, generally confirming previously stated hypothesis on their effects (Table 3). Tourists with repeated visits express less interest in visiting the most popular tourist locations during their stay in the city, and were focused on a select few locations. On the other hand, first time visitors wanted to see as many tourist attractions as possible. This study recorded statistically significant differences between first time and repeat visitors for the Belgrade fortress $(\mathrm{F}=18.85, \mathrm{p}<.01)$, National Assembly of the Republic of Serbia $(F=28.87, p<.05)$ and floating river clubs $(F=16.69, p<.05)$. Differences in length of stay in Belgrade were reflected in patterns of participants' spatial behaviour, especially in the number and importance of the sites visited. Therefore, Ada Ciganlija $(\mathrm{F}=25.14, \mathrm{p}<.01)$ and floating river clubs $(\mathrm{F}=$ $16.05, \mathrm{p}<.01$ ) were far more visited by tourists who stayed three or more nights than by the two other groups. Lack of time can also explain the absence of daily visitors to the Bohemian Quarter, where tourists usually spend time in restaurants or enjoying the nightlife $(\mathrm{F}=4.88, \mathrm{p}<.01)$.

\section{Conclusion}

This paper attempts to explain the spatial behaviour of foreign tourists in Belgrade. The results confirmed the importance of the Belgrade historic centre for tourism, but also stressed the necessity of creating long term strategies that 
will promote a more balanced and polycentric distribution of tourist activities in Belgrade. Tourist attractions located outside of Old Belgrade were not adequately visited by interviewed tourists. Virtual absence of city sites with tourist potential in their itineraries and mental maps, such is the case with the core of Zemun with preserved Austro-Hungarian architecture, reveals poor integration of slightly peripheral tourist resources to the main attractions aggregated in Old Belgrade.

Delimitation of urban areas that tourists intensively use during their stay allows urban institutions and authorities to more efficiently allocate and utilize resources, manage conservation of the architectural and cultural heritage, extend pedestrian zones, support development of tourist services, etc. However, the improvement of city tourism should not be limited to main tourist zones, rather to crucially expand tourist function within peripheral areas. A polycentric and diversified touristic offer can satisfy various tourist needs and interests, which in turn result in a wholesome tourist experience, longer stay and greater positive impact on the local economy. Polycentric development of tourism includes the modernization of the transport system, which should more efficiently connect peripheral tourist attractions with the city centre, proper tourist signalization, additional marketing activities that would introduce peripheral attractions to tourists, adaptation of existing and development of new tourist attractions. The authors state that, although negative consequences of the largely mono-centric development of tourism in Belgrade have not yet been documented, the decentralization of urban tourism should be considered in advance, in order to avoid future negative effects of tourism on the city.

The analysis of the influence of socio-demographic and trip characteristics on the spatial behaviour generated information that could be utilized in tourism development strategies within Belgrade. Research results showed that wealthier visitors are more interested in visiting the main pedestrian area filled with shops and restaurants, city's bohemian quarter and floating river clubs. This segment of tourists is appealing not only because of its purchasing power but also for its additional motivation to visit sites outside the historic centre. Results related to behaviour of the non-European tourists, who visited fewer sites, which were almost exclusively located in the historic city core, could be interesting for the city's tourism management and marketing. In the forthcoming period, increased number of arrivals from non-European countries can be expected, which is why it is necessary to make more effort to advertise and promote more peripheral tourist sites (World Tourism Organization \& European Travel Commission, 2010). Findings about the younger visitors being more attracted to the Ada Ciganlija Lake, as well as male visitors being more attracted to floating river clubs are somewhat expected. Results from the study based on the character of trips made by tourists signify that extended their stay by improving and diver- 
sifying the offer made to tourists, would contribute to higher visitation of sites outside the Old Belgrade, which in turn would support a more balanced and sustainable tourism development with lower pressure placed upon the most attractive and centrally located sites.

\section{Acknowledgement}

The paper is the result of a research project 176017, which is financed by the Ministry of Education, Science and Technological Development of the Republic of Serbia.

We would like to express special gratitude to the students of the Faculty of Geography in Belgrade Nikola Todorović, Jelena Apelić, Gorana Romić, Nevena Ivanović and Tamara Maslaković for assistance in the survey of tourists.

\section{References}

Ashworth, G.J., \& Page, J.S. (2011). Urban Tourism Research: Recent Progress and Current Paradoxes. Tourism Management, 32(1), 1-15.

Ashworth, G.J., \& Tunbridge, J.E. (2000). The Tourist-Historic City. Amsterdam: Pergamon.

Association for Education on Tourism and Leisure (2014). Questionnaire Modules. Retrieved from: http://www.tram-research.com/atlas/survey 2007.htm, [Accessed: 20 April 2017].

Balint, K. (2014). Measuring tourist activities in cities using geotagged photography. Tourism Geographies, 16(1), 88-104.

Belgrade City Institute for the Protection of Cultural Monuments (2015). Zaštićene celine. Retrieved from http://beogradskonasledje.rs/заштићене-целине, [Accessed: 16 November 2015].

Budović, A., Šljuka, A., \& Ratkaj, I (2015). Georeferenced photographs as a data source for analyzing tourist spatial behavior in Belgrade. In Proceedings of the 4 th Serbian Congress of Geographers, Kopaonik, Serbia, 7-9 October 2015 (pp. 75-79). Belgrade: University of Belgrade - Faculty of Geography \& Serbian Geographical Society

Cartwright, G. (2009). "Dancing on the Danube", The Guardian, [online] 25 July. Retrieved from: <http://www.theguardian.com/travel/2009/jul/ 25/belgrademusic-serbia-gypsy-techno>, [Accessed: 25 November 2017].

Chen, B., Yang, K., \& Wang, J. (2017). Research of the distribution of tourists' attributes based on internet data: A case study of Kunming. IOP Conference Series: Materials Science and Engineering, 231(1), 12-46. 
Chen, C., \& Chang, W., \& Chang, W. (2009). Gender differences in relation to wayfinding strategies, navigational support design, and wayfinding task difficulty. Journal of Environmental Psychology, 29, 220-226.

Cohen, B. (2013). Where folk songs meet Serbian criminals, www.bbc.co.uk, [online] 27 October, Retrieved from: <http://www.bbc.com/travel/feature/ 20131017-where-folk-songs-meet-serbian-criminals>, [Accessed: 25 November 2017].

Debbage, K. (1991). Spatial Behavior in a Bahamian Resort. Annals of Tourism Research, 18(2), 251-268.

Edwards, D, Dickson, T.J., Griffin, T. \& Hayllar, B.R. (2010). Tracking the urban visitor: Methods for examining tourists' spatial behaviour and visual representations. In Richards, G. \& Munsters, W. (eds), Cultural Tourism Research Methods (pp. 104114). UK: CABI.

Edwards, D., \& Griffin, T. (2013). Understanding tourists' spatial behaviour: GPS tracking as an aid to sustainable destination management. Journal of Sustainable Tourism, 21(4), 580-595.

Fennell, D. (1996). A Tourist Space-time Budget in the Shetland Islands. Annals of Tourism Research, 23, 811-829.

Fleischer, A., \& Pizam, A. (2002). Tourism constraints among Israeli seniors. Annals of Tourism Research, 29(1), 106-123.

Freytag, T. (2010). Being a tourist in Heidelberg: Exploring visitor activities and spatial mobility in the city. Revista Geografica Italiana, 117(2), 379-389.

Gali-Espelt, N. \& Donaire-Benito, J.A. (2006). 'Visitors' behavior in heritage cities: The case of Girona. Journal of Travel Research, 44(4), 442-48.

Golledge, R. (2008). Behavioral Geography and the Theoretical/Quantitative Revolution. Geographical Analysis, 40, 239-257.

Grčić, M. (1994). Industrijska geografija. Beograd: Naučna knjiga.

Grčić, M. (2012). Ekonomska geografija[Skripta]. Beograd: Ekonomski fakultet.

Jovičić, D. (2008). Uvod u turizmologiju i turističku geografiju. Novi Beograd: Ton PLUS.

Kadar, B. (2014). Measuring tourist activities in cities using geotagged photography. Tourism Geographies, 16(1), 88-104.

Kadar, B., \& Gede, M. (2013). Where do tourists go? Visualizing and analysing the spatial distribution of geotagged photography. Cartographica: The International Journal for Geographic Information and Geovisualization, 48(2), 78-88.

Kempermann, A., Chang-Hyeon, J., \& Timmermans, H. (2004). Comparing first-time and repeat visitors' activity patterns in a tourism environment. In G.I. Crouch, R.R. Perdue, \& H.J.P. Timmermans (Eds.), Consumer psychology of tourism, hospitality and leisure (vol. 3, pp. 103-119). Wallingford: CABI.

Keul, A., \& Kühberger, A (1997). Tracking the Salzburg Tourist. Annals of Tourism Research, 24, 1008-1012. 
McKercher B. (2001). A comparison of main destination and through travellers at a dual purpose destination. Journal of Travel Research, 39(4), 433-448.

McKercher, B., \& Lau, G. (2008). Movement Patterns of Tourists within a Destination. Tourism Geographies, 10(3), 355-374.

McKercher, B., Shoval, N., Ng, E., \& Birenboim, A. (2012). First and repeat visitor behaviour: GPS tracking and GIS analysis in Hong Kong. Tourism Geographies, 14(1), 147-161.

McKercher, B., Wong, C., \& Lau, G. (2006). How tourists consume a destination. Journal of Business Research, 59, 647-652.

Mok, C., \& Iverson, T. (2000). Expenditure-based segmentation: Taiwanese tourists to Guam. Tourism Management, 21(3), 299-305.

Murphy, P. E (1992). Urban Tourism and Visitor Behavior: growing significance of urban tourism case. The American Behavioral Scientist, 36(2), 200-2011.

Neuts, B., \& Nijkamp, P. (2012). Tourist crowding perception and acceptability in cities: An applied modelling study on Bruges. Annals of Tourism Research, 39(4), 2133-2153.

Pearce, D.G. (2001). An integrative framework for urban tourism research. Annals of Tourism Research, 28(4), 926-946.

Ratkaj, I. (2012). Spatial differentiation of Belgrade according to the degree of urbanity. Collection of Papers - University of Belgrade - Faculty of Geography, 60, 105-132.

Secretariat for Administration - Sector for statistics (2016). Statistical Yearbook of Belgrade (2015). Belgrade: Secretariat for Administration - Sector for statistics.

Shachar, A., \& Shoval, N. (1999). Tourism in Jerusalem: A place to pray'. In D. Judd and S.S. Fainstein (eds), The Tourist City (pp. 198-211). New Haven: Yale University Press.

Sherwood, S. (2005). Belgrade Rocks, The New York Times, [online] 16 October. Retrieved from: <http://www.nytimes.com/2005/10/16/travel/16 belgrade. html?_r=0>, [Accessed: 25 November 2017].

Shoval, N. (2012). Time geography and tourism. In J. Wilson (Ed.), The Routledge handbook of tourism geographies (pp. 174-180). London: Routledge.

Shoval, N., \& Isaacson, M. (2007). Tracking tourists in the digital age. Annals of Tourism Research, 34(1), 141-159.

Shoval, N., \& Isaacson, M. (2010). Tourist Mobility and Advanced Tracking Technologies. London: Routledge.

Shoval, N., McKercher, B., Ng, E., and Birenboim, A. (2011). Hotel location and tourist activity in cities. Annals of Tourism Research, 38(4), 1594-1612.

Todorović, N., Apelić, J., \& Romić, G. (2015). Characteristics of foreign youth tourism in Belgrade. Bulletin of the Serbian Geographical Society, 95(3), 1-16. 
Todorović, N., Deđanski, V. (2016). Značaj i razmeštaj turističkih atrakcija u Beogradu. Četurti kongres geografa Bosne i Hercegovine, Sarajevo 17-19. novembar (str. 129). Sarajevo: Prirodno-matematički fakultet.

Todorović, N., Manojlović, I., \& Budović, A. (2017). Measuring tourist satisfaction and destination image with HOLSAT. Bulletin of the Serbian Geographical Society, 97(2), 87-118.

Versichele, M., Neutens, T., Delafontaine, M., \& Van de Weghe, N. (2012). The use of Bluetooth for analysing spatiotemporal dynamics of human movement at mass events: A case study of the Ghent Festivities. Applied Geography, 32(2), 208-220.

Vu, HQ., Li, G., Law, R., \& Ye, BH. (2015). Exploring the travel behaviors of inbound tourists to Hong Kong using geotagged photos. Tourism Management, 46, 222-232.

World Tourism Organization \& European Travel Commission (2010). Demographic Change and Tourism. Madrid: UNWTO.

Xia, J. (2007). Modelling the spatial-temporal movement of tourists [PhD Thesis]. Melbourne: RMIT University.

Yan, L.J. (2003). A cross-national analysis of international tourist flows in China. Tourism Geography, 5(3), 257-79.

Zoltan, J., \& McKercher, B. (2015). Analysing intra-destination movements and activity participation of tourists through destination card consumption. Tourism Geographies, 17(1), 19-35. 